\title{
Comparison of the carbon-sequestering abilities of pineapple leaf residue chars produced by controlled combustion and by field burning
}

\begin{abstract}
This study was undertaken to compare the chemical properties and yields of pineapple leaf residue (PLR) char produced by field burning (CF) with that produced by a partial combustion of air-dried PLR at $340{ }^{\circ} \mathrm{C}$ for $3 \mathrm{~h}$ in a furnace (CL). Higher total C, lignin content, and yield from CL as well as the presence of aromatic compounds in the Fourier Transform Infrared spectra of the char produced from CL suggest that the CL process was better in sequestering $\mathrm{C}$ than was the $\mathrm{CF}$ process. Although the $\mathrm{C} / \mathrm{N}$ ratio of char produced from $\mathrm{CL}$ was low indicating a high $\mathrm{N}$ content of the char, the $\mathrm{C}$ in the char produced from $\mathrm{CL}$ was dominated by lignin suggesting that the decomposition of char produced from CL would be slow. To sequester $\mathrm{C}$ by char application, the PLR should be combusted in a controlled process rather than by burning in the field.
\end{abstract}

Keyword: Pineapple leaf residue; Char; Carbon; FTIR spectra; Lignin 